European Journal of Logistics, Purchasing and Supply Chain Management

Vol.8 No.2, pp.24-34, May 2020

Published by ECRTD UK

ISSN 2054-0930 (Print), ISSN 2054-0949 (Online)

\title{
ADOPTION OF LOGISTICS PLANNING MODEL IN EVALUATING THE PERFORMANCE OF SPDC-BASED LOGISTICS FIRMS, NIGERIA
}

\author{
Aju, U. O., Ukaegbu, S.I., Ejem, E.A and Ikeogu, V. N. \\ Department of Transport Management Technology, \\ Federal University of Technology, Owerri, Imo State, Nigeria
}

\begin{abstract}
The paper proffers that logistics planning processes are dynamic capabilities because of improvement in logistics competitive capabilities and enhanced disaster immunity. Data from a sample of 230 top/middle managers representing different SPDC-based logistics firms were randomly selected from the Nigerian logistics employees are analyzed using a structural equation modelling methodology. The findings suggest that logistics planning influences financial performance via improvement in logistics, competitive capability and enhanced disaster immunity in SPDC-based Logistics firms. Further, the results indicate that when an SPDC-based Logistics firm employs mindful-planning processes, an essential element within logistics planning, it can avoid the trade-off between risk management and efficiency. Thus, when firms hire logistics planning, they gain a competitive advantage, which improves financial performance. The results indicate that logistics performance is positively impacted by logistics planning strategy and that both logistics performance and logistics planning strategy positively impact marketing performance, which in turn positively impacts financial performance. Both logistics planning strategy and logistics performance were found to affect financial performance directly. As SPDCbased Logistics firms work to improve the logistics processes, they support their organization's logistics planning strategy, resulting in improved performance for the overall supply chain.
\end{abstract}

KEYWORDS: Logistics planning, supply-chain, disaster-immunity, competitive-capabilities, SPDC

\section{INTRODUCTION}

De Kluyver and Pearce (2006) opines that the ultimate goal of the strategy is "long-term, superior sustainable performance." Such superior performance now depends on the ability of a logistics organization to become a fully integrated partner within a supply chain context (Cooper et al., 1997), thus all but requiring that logistics organizations adopt a supply chain strategy. Such supply chain strategies focus on how both internal and external business processes can be integrated and coordinated throughout the supply chain to serve ultimate customers and consumers better while enhancing the performance of the individual supply chain members (Cohen and Roussel, 2005). Examples of business processes that must be integrated include logistics, purchasing, selling, logistics, and the delivery of real-time, seamless information to all supply chain partners. Managing at the supply chain level requires a new focus and new ways of operating (Lambert et al., 1998). Logistics managers must learn to communicate, coordinate, and cooperate with supply chain partners (Gammelgaard and Larson, 2001). 
Complex logistics operations make global supply chains susceptible to sudden, and possibly prolonged, disruptive events. Not surprisingly, supply-chain risk management remains a critical issue (Rao and Goldsby, 2009; Ghadge et al., 2012), both from the perspective of proactively reducing risks as well as reacting swiftly and effectively when a crisis event occurs. Historically, businesses have employed logistics planning for reducing risk and maintaining operational continuity under crises events. Past logistics planning research has yielded an extensive body of knowledge and great insight; however, only recently has the focus shifted from a functional perspective to an enterprise-wide focus (Elliott et al., 1999), to include the broader ecosystem of a firm's value chain (Benyoucef and Forzley, 2007).

Logistics planning research is just at the nascent stage, indicating a lack of literature exploring contingency planning within global supply-chain management. Researchers have begun defining supply-chain logistics planning, developing measures of logistics planning and evaluating the impact of a contingency planning on organizational-level outcomes such as strategic flexibility. Despite this recent work, essential questions concerning the relationships between business continuity, operational capabilities, and financial performance have yet to be answered. In particular, there is an absence of rich theory to explain better the trade-offs between maintaining organizational efficiencies and minimizing risk management within complex supply chains. Furthermore, the degree of importance of logistics support to a facility is dependent on the level of exposure of the facility to environmental hazard and disaster as well as the economic viability. These need to be prevented. Hence the need for supply of spares from the coastal locations requiring strategic logistics planning because in the event of a fire from any of them the whole asset could be lost or sustain significant damages that will need multiple millions of dollars to repair. To move research forward, we investigate the importance of logistics planning, which we define as logistics planning principles applied to logistics within supply chains.

\section{LITERATURE REVIEW}

Mindful planning enables a firm's organization continuity, manifested in both its competitive logistics capability (LCC) and Disaster Immunity (DI). It relates our research model, which extends the HRT (high-reliability theory) framework; specifically, we embed mindful planning within the logistics planning construct. The reconciliation of HRT logic with the proposed logistics planning construct reflects our fundamental argument that logistics planning instils mindfulness in a firm. It helps the firm simultaneously develop and exploit two complementary capabilities: LCC (competitive logistics capability) and DI (Disaster Immunity). These two capabilities are additional because they help firms manage the tension inherent in the trade-off between efficiency (LCC) and risk management (DI). Further, these dynamic capabilities provide the firm strategic flexibility, which enhances the viability and sustains FINP.

We contend that the five principles of mindful planning correspond with the nine dimensions of logistics planning, as described in (Ojha and Gokhale, 2009). First, as firms rapidly establish ad hoc structures to deal with fast-changing crisis environments, the structuring mechanism for logistics planning is primarily driven by employee awareness of roles and responsibilities as well as knowledge of contact points (Bigley and Roberts, 2001). These elements are critical to avoid 
the limitations of bounded rationality; decisions should be made by people who have in-depth knowledge of the system under crisis (Simon, 1957). Knowledgeable employees, irrespective of hierarchy, must be granted decision-making authority as they have access to the relevant information and expertise to make informed decisions about complex situations (Bigley and Roberts, 2001; Mallak, 1998). Cotton (1993), when papering Los Angeles riots of 1992, provides an example of how clearly defined roles and responsibilities facilitated the management of emergency operations. Thus, the dimensions of awareness of contact points and roles and responsibilities correspond to deference to expertise dimension of mindfulness.

Second, organizations that implement logistics planning are considered vigilant because they are aware of how things can and will go wrong (Reason, 2000). As a consequence, many organizations catalogue previous failures - the sources of and the impact inflicted on the organization. This database provides the necessary information to adapt crisis prevention and recovery plans as they now have an inbuilt early warning system to anticipate the next crisis (Turner, 1976; Webb et al., 2002; Pearson and Mitroff, 1993). Analysis of past failures also surfaces faulty assumptions that help organizations unlearn adverse behaviours and incorporate new practices, which in turn help reduce organizational vulnerabilities (Carmeli and Schaubroeck, 2008). This obsession with failure and failure recovery is what Weick and Sutcliffe (2006) call preoccupation with failures.

Third, logistics planning implementation involves awareness and impact of potential threats to business operations, as well as the level of operational resilience needed to respond to these threats (British Standards Institution, 2006). The level of functional resistance is reflected in continuity and recovery service levels (Tierney, 2003). This operational awareness helps organizations effectively respond to crises because it is the first trigger for taking action (Crichton et al., 2005; Roth et al., 2006). Thus, we suggest that the two dimensions of logistics planning - awareness of risk levels and the awareness of continuity and recovery service levels - reflect an organization's sensitivity to its operations.

Fourth, an essential aspect of logistics planning is continuity testing and reviewing the actual plans. This behaviour is a result of in-depth knowledge of the organization's operations and provides employees with a more nuanced view of its services complexity and coupling, thus discouraging standardized responses (Boin and Lagadec, 2000; Turner, 1976). In other words, organizations will periodically evaluate their logistics planning processes, even after implementation, and update them based upon environmental changes. The reduced emphasis on standardized response to crisis grows out of the realization that all emergencies are mostly unique, and the same intervention may not be effective in all crisis scenarios. This departure from a simplistic assumption is built into the logistics planning process through the twin activities of plan testing and plan review. This departure is what Weick and Sutcliffe (2006) term as reluctance to simplify.

Finally, having a logistics planning reflects an organization's commitment to operational safety and reliability (British Standards Institution, 2006; Pearson and Clair, 1998; McManus, 2007; Elwood, 2009; Alexander, 2005). To achieve these goals, firms emphasize employee training for creating and managing effective logistics planning (Vecchio, 2000; Carthey et al., 2001). Emphasis on safety and reliability represents an organization's commitment to resilience (Weick and 
Vol.8 No.2, pp.24-34, May 2020

Published by ECRTD UK

ISSN 2054-0930 (Print), ISSN 2054-0949 (Online)

Sutcliffe, 2006). In sum, we have demonstrated how the five dimensions of mindful planning, encapsulated in the HRT (high-reliability theory) principles, correspond with the eight aspects of logistics planning.

A decade ago, Morash and Clinton (1997) suggested a model for future supply chain research which included transport and logistics capabilities as the link between supply chain structure and performance. While Wisner (2003) hypothesized a definite relationship between logistics strategy and operational performance, but failed to report data collection in logistics strategy measurement. He did not capture results related to his hypotheses. Schramm-Klein and Morschett (2006) estimated the relationship between logistics quality and the operational performance of organisations in the retail sector.

It is our purpose to build on the work of Schramm-Klein and Morschett (2006), Wisner (2003), and Morash and Clinton (1997) by empirically investigating the link between logistics performance and organizational performance in the logistics sector. We propose a logistics performance model that incorporates logistics performance as the focal construct with logistics planning as antecedent and organizational performance, both financial and marketing, as consequences. Although the model as proposed is original, it does build upon and extend the works of Green et al. (2006) and Wisner (2003).

A logistics planning requires an end-to-end supply chain focus that supports the integration of business processes such as purchasing, logistics, selling, and logistics throughout the chain to provide satisfactory value to the eventual customer/consumer (Cohen and Roussel, 2005; Wisner, 2003). The operationalization of such a strategy involves that steps be taken to boost relationships and ensure trust among supply chain operators to expedite the incorporation of processes throughout the supply chain from suppliers' supplier to final consumer/consumer (Cohen and Roussel, 2005; Wisner, 2003). The logistics performance model shows the organization's recital as it concerns its ability to deliver goods and services in the expected amount and at the specific times expected by customers. Bowersox et al. (2000) incorporate performance indicators such as customer satisfaction, delivery speed, delivery dependability, and delivery flexibility. Marketing performance shows the organization's ability to boost sales and increase market share as viz-a-viz its competition (Green and Inman, 2005; Green et al., 2006). Financial performance depicts an organization's profitability and returns on investment in relation to its competition (Claycomb et al., 1999; Green et al., 2004; Green and Inman, 2005).

\section{METHODOLOGY}

The paper adopted a logistics planning scale from Ojha and Gokhale (2009). The logistics planning is a 25-item multidimensional scale with nine first-order factors - awareness of contact points (C.P.), awareness of Roles and Responsibilities (R.R.), Awareness of Risk Levels (R.L.), Awareness of Continuity and Recovery Service Levels (CRSL), Institution of Business Continuity Reviews (BCR), Development of Business Continuity Processes, Failure Reporting and Documentation (FRD), Testing of Continuity Plans (TEST), Training of Employees to Create and Execute Continuity Plans (TRAIN). DI (Disaster Immunity): A three-item DI scale was adapted 
Vol.8 No.2, pp.24-34, May 2020

Published by ECRTD UK

ISSN 2054-0930 (Print), ISSN 2054-0949 (Online)

from Ojha (2008). The items capture SPDC-based logistics firms' ability to avoid disasters, minimize the impact of disasters, and recover efficiently from disasters as compared to their competitors (see Appendix for further details). LCC (Logistics Competitive Capability): The logistics competitive capabilities scale was developed for this paper based on the work of Rosenzweig et al. (2003). The scale captures the effectiveness of the sampled SPDC-based logistics firms relative to their competitors on service quality and reliability. FINP: The FINP measures were based on Chen and Paulraj (2004). They captured the competitive FINP of the business units using items relating to return on investment (ROI), profit as a percentage of sales and, net income before tax.

A total of 350 top and middle management staff representing different SPDC-based logistics firms were randomly selected from the Nigerian logistics employees. These managers were surveyed using a traditional initial and follow-up mailing procedure for over six months in 2018.

\section{RESULTS AND DISCUSSIONS}

For scale validity of the model, we assessed the discriminant validity of each scale used in the paper. Convergent validity is established if the items load significantly on their respective factors, and for the second-order factors, all the first-order factor loadings are significant. As demonstrated in Table 2, all the item loadings on their separate factors were highly significant $(\mathrm{p}<0.001)$. The loadings of first-order factors on the second-order logistics planning factors are also significant $(\mathrm{p}<0.001)$. Furthermore, the loadings of items on their respective first-order factors as well as the loadings of first-order factors on the second-order logistics planning factor are all above 0.60. Thus, the scales have convergent validity.

The test of discriminant validity of the scales was done using Wilks' Lamda. The fixed and free model comparison involves fixing the correlation between constructs being evaluated to 1 , whereas, in the free model, the relationships are freely estimated. The fixed and free model test could involve the omnibus test of discriminant validity where all the constructs are simultaneously evaluated, or it could include pair-wise comparison. The $\chi^{2}$ difference between omnibus fixed and free models (without the control variables) is highly significant $\left(\Delta \chi^{2}=1515.854, \mathrm{p}<0.001\right)$ indicating that the free model is a superior model. Furthermore, all the other fit indices of the free model are much better than the fixed model. Besides, Table 1 reports the pair-wise comparison of fixed and free models as signs indicating that the free models have a better fit than the attached models. Therefore, we have additional support that construct scales have discriminant validity. Finally, we assessed the measurement model. The fit indices of the measurement model, which included the control variables, were entirely satisfactory $\left(\chi^{2}=631.458, p<0.001\right)$. In summary, analyses discussed above provide adequate evidence of convergent as well as discriminant validity of the scales used in this paper. 
European Journal of Logistics, Purchasing and Supply Chain Management

Vol.8 No.2, pp.24-34, May 2020

Published by ECRTD UK

ISSN 2054-0930 (Print), ISSN 2054-0949 (Online)

Table 1: Summary of Canonical Discriminant Functions

\begin{tabular}{|l|r|r|r|r|}
\hline Function & Eigenvalue & \% of Variance & Cumulative \% & Canonical Correlation \\
\hline 1 & $49.498^{\mathrm{a}}$ & 76.2 & 76.2 & .990 \\
\hline 2 & $15.449^{\mathrm{a}}$ & 23.8 & 100.0 & .969 \\
\hline
\end{tabular}

a. First two canonical discriminant functions were used in the analysis.

Table 2: Wilks' Lambda

\begin{tabular}{|l|r|r|r|r|}
\hline Test of Function(s) & Wilks' Lambda & Chi-square & df & \multicolumn{1}{|c|}{ Sig. } \\
\hline 1 through 2 & .001 & 1515.854 & 8 & .000 \\
\hline 2 & .061 & 631.458 & 3 & .000 \\
\hline
\end{tabular}

Also, we try to test the statistical significance of the causal factors used in the logistics planning model.

Table 3: $\chi^{2}$ Test Statistics

\begin{tabular}{|l|l|l|l|l|l|l|l|l|l|l|l|}
\hline & FINP1 & FINP2 & FINP3 & LCC1 & LCC2 & LCC3 & LCC4 & LCC5 & DI1 & DI2 & DI3 \\
\hline Chi-Square & $6.009^{\mathrm{a}}$ & $35.748^{\mathrm{a}}$ & $27.922^{\mathrm{a}}$ & $160.652^{\mathrm{a}}$ & $123.243^{\mathrm{a}}$ & $81.765^{\mathrm{a}}$ & $211.522^{\mathrm{a}}$ & $123.243^{\mathrm{a}}$ & $97.104^{\mathrm{a}}$ & $65.017^{\mathrm{a}}$ & $27.922^{\mathrm{a}}$ \\
\hline Df & 2 & 2 & 2 & 2 & 2 & 2 & 2 & 2 & 2 & 2 & 2 \\
\hline Asymp. Sig. & .050 & .000 & .000 & .000 & .000 & .000 & .000 & .000 & .000 & .000 & .000 \\
\hline
\end{tabular}

The test of the causal structure for our hypothesized model is done with the $\chi^{2}$ test. We first evaluate the overall model structure using the fit indices for the hypothesized research model. Fit indices of our causal model (e.g. for FINP1 $\chi^{2}=6.009, \mathrm{p}<0.001$ ) meet the recommended cutoffs for a good fit. Also, the fit of the structural model is statistically similar to the measurement model in Kruskal Wallis test $\left(\Delta \chi^{2}=186.055, \mathrm{p}<0.001\right)$ indicating that the hypothesized model is a good representation of the covariance structure of the data.

Table 4: Kruskal Wallis Test Statistics ${ }^{a, b}$

\begin{tabular}{|l|l|l|l|l|l|l|l|l|l|l|l|}
\hline & FINP1 & FINP2 & FINP3 & LCC1 & LCC2 & LCC3 & LCC4 & LCC5 & DI1 & DI2 & DI3 \\
\hline Chi-Square & 186.055 & 195.175 & 148.816 & 60.791 & 162.805 & 129.472 & 95.357 & 160.379 & 207.338 & 152.221 & 71.394 \\
\hline df & 2 & 2 & 2 & 2 & 2 & 2 & 2 & 2 & 2 & 2 & 2 \\
\hline Asymp. Sig. & .000 & .000 & .000 & .000 & .000 & .000 & .000 & .000 & .000 & .000 & .000 \\
\hline
\end{tabular}

a. Kruskal Wallis Test

b. Grouping Variable: LP

We evaluated the direct effects of the causal model, using a significance test of the best model statistics (see Table 5). That logistics planning has a positive impact DI1, was supported ( $\beta=0.841$, $\mathrm{p}<0.001)$. Logistics planning has a positive impact on LCC1, was not recommended $(\beta=-0.822$, $\mathrm{p}<0.001)$. That LCC5 harms L.P. with $(\beta=-0.751, \mathrm{p}<0.001)$. Similarly, DI2 has a positive impact on L.P., was also supported $(\beta=1.196, \mathrm{p}<0.001)$. Finally, DI3 has a positive effect on L.P., was not supported as well $(\beta=-0.262, \mathrm{p}<0.001)$. 
European Journal of Logistics, Purchasing and Supply Chain Management

Vol.8 No.2, pp.24-34, May 2020

Published by ECRTD UK

ISSN 2054-0930 (Print), ISSN 2054-0949 (Online)

Table 5: Best Model Statistics Coefficients

\begin{tabular}{|c|c|c|c|c|c|c|}
\hline & \multirow{2}{*}{\multicolumn{2}{|c|}{ Unstandardized Coefficients }} & \multirow{2}{*}{\multicolumn{2}{|c|}{ Standardized Coefficients }} & \multirow[b]{3}{*}{$\mathrm{t}$} & \multirow[b]{3}{*}{ Sig. } \\
\hline & & & & & & \\
\hline & B & Std. Error & Beta & Std. Error & & \\
\hline (Constant) & 3.730 & .038 & & & 97.091 & .000 \\
\hline LCC1 & -1.000 & .008 & -.822 & .006 & -128.046 & .000 \\
\hline LCC5 & -.746 & .008 & -.751 & .008 & -90.678 & .000 \\
\hline DI1 & 1.000 & .009 & .841 & .007 & 117.131 & .000 \\
\hline DI2 & 1.254 & .011 & 1.196 & .011 & 110.163 & .000 \\
\hline DI3 & -.254 & .006 & -.262 & .006 & $\mid-44.352$ & .000 \\
\hline
\end{tabular}

Lastly, we examined the effects of control variables in our structural model: FINP, LCC and DI (Table 5). We included these three variables because each was modelled to cause DI, LCC, and FINP, respectively. All of the effects of these control variables were significant except that of the LCC on L.P. ( $p>0.001)$. It implies that the availability of slack resources may help in preventing and avoiding disruption in SPDC-based logistics firms.

Predictive validity was assessed by determining whether the scales of interest correlate as expected with other measures. A review of the correlation matrix (Table 6) for the paper values supports claims of predictive validity for each paper variable. The paper variables are positively correlated with the coefficients significant at the 0.01 level except for LCC2-LCC5.

Table 6: Logistics Planning Paired Samples Correlations

\begin{tabular}{|l|l|l|l|l|}
\hline & & $\mathrm{N}$ & Correlation & Sig. \\
\hline Pair 1 & LP \& FINP1 & 230 & .466 & .000 \\
\hline Pair 2 & LP \& FINP2 & 230 & .606 & .000 \\
\hline Pair 3 & LP \& FINP3 & 230 & .576 & .000 \\
\hline Pair 4 & LP \& LCC1 & 230 & .085 & .200 \\
\hline Pair 5 & LP \& LCC2 & 230 & .057 & .390 \\
\hline Pair 6 & LP \& LCC3 & 230 & .045 & .497 \\
\hline Pair 7 & LP \& LCC4 & 230 & .048 & .472 \\
\hline Pair 8 & LP \& LCC5 & 230 & .064 & .331 \\
\hline Pair 9 & LP \& DI1 & 230 & .717 & .000 \\
\hline Pair 10 & LP \& DI2 & 230 & .539 & .000 \\
\hline Pair 11 & LP \& DI3 & 230 & .445 & .000 \\
\hline
\end{tabular}

Summary values for the SPDC-based logistics firms' variables were computed by averaging across the items in the scales. The correlation matrix for the summary variables is presented in Table 6. All correlation coefficients are positive, and some are significant at the 0.01 level except for LCC1LCC5. The relationship between logistics planning and financial performance is significant at the 0.05 level with an estimate of 0.109 and t-value of 2.049 (see Table 7). The forecast of -0.213 for the relationship between logistics planning and DI1 is significant at the 0.05 level with a t-value of -5.905. The relationship between logistics planning and LCC1 is substantial with an estimate of -0.591 and $t$-value of -8.731 
Table 7: Paired Samples Test

\begin{tabular}{|c|c|c|c|c|c|c|c|c|c|}
\hline & & \multirow{2}{*}{\multicolumn{5}{|c|}{ Paired Differences }} & & & \\
\hline & & & & & & & \multirow[b]{3}{*}{$\mathrm{t}$} & \multirow[b]{3}{*}{$\mathrm{df}$} & \multirow[b]{3}{*}{$\begin{array}{l}\text { Sig. (2- } \\
\text { tailed) }\end{array}$} \\
\hline & & \multirow[b]{2}{*}{ Mean } & \multirow[b]{2}{*}{$\begin{array}{c}\text { Std. } \\
\text { Deviation }\end{array}$} & \multirow[b]{2}{*}{$\begin{array}{l}\text { Std. Error } \\
\text { Mean }\end{array}$} & \multicolumn{2}{|c|}{$\begin{array}{l}95 \% \text { Confidence } \\
\text { Interval of the } \\
\text { Difference }\end{array}$} & & & \\
\hline & & & & & Lower & Upper & & & \\
\hline Pair 1 & LP - FINP1 & .109 & .805 & .053 & .004 & .213 & 2.049 & 229 & .042 \\
\hline Pair 2 & L.P. - FINP2 & -.109 & .662 & .044 & -.195 & -.023 & -2.491 & 229 & .013 \\
\hline Pair 3 & L.P. - FINP3 & -.174 & .696 & .046 & -.264 & -.083 & -3.788 & 229 & .000 \\
\hline Pair 4 & L.P. - LCC1 & -.591 & 1.027 & .068 & -.725 & -.458 & -8.731 & 229 & .000 \\
\hline Pair 5 & L.P. - LCC2 & -.448 & 1.067 & .070 & -.586 & -.309 & -6.363 & 229 & .000 \\
\hline Pair 6 & L.P. - LCC3 & -.383 & 1.122 & .074 & -.528 & -.237 & -5.171 & 229 & .000 \\
\hline Pair 7 & L.P. - LCC4 & -.657 & .953 & .063 & -.780 & -.533 & -10.451 & 229 & .000 \\
\hline Pair 8 & L.P. - LCC5 & -.465 & 1.047 & .069 & -.601 & -.329 & -6.736 & 229 & .000 \\
\hline Pair 9 & L.P. - DI1 & -.213 & .547 & .036 & -.284 & -.142 & -5.905 & 229 & .000 \\
\hline Pair 10 & LP - DI2 & -.061 & .697 & .046 & -.151 & .030 & -1.325 & 229 & .186 \\
\hline Pair 11 & L.P. - DI3 & -.196 & .799 & .053 & -.299 & -.092 & -3.714 & 229 & .000 \\
\hline
\end{tabular}

\section{CONCLUSION}

Generally, the results support the proposition that the adoption of logistics planning leads to improved operational performance, as measured by logistics performance, which in turn leads to improved organizational performance. The logistics function, however, is an externally focused supply chain function that has global, as well as local, implications for managers in the logistics sector. Our findings support the notion that SPDC-based logistics firms cultivate collective mindfulness when creating logistics planning. This mindfulness not only effectively helps an organization avoid and recover from disaster, but just as importantly, enables delivery of reliable service. In this sense, we demonstrate how firms can avoid the trade-off between risk management (DI) and efficiency (LCC). SPDC-based logistics firms manage this trade-off by enacting a state of the attentive problem and solution discovery, resulting in potential solutions that create a varied action repertoire, but not system-threatening contradictions. An enlarged action repertoire provides a variety of interventions to rectify problematic situations.

Second, our findings support the conjecture that, by leveraging logistics planning principles, SPDC-based logistics firms provide better service quality and achieve DI, which significantly improves their FINP. Although there are several normative conceptual and process frameworks for logistics planning, we offer the first empirical test of the relationship between logistics plan and firm-level FINP. We also establish how careful planning processes, encompassed in logistics planning, affect FINP through the modification of operational routines formed within LCC and DI. Therefore, we show that logistics planning is a dynamic capability that indirectly enables SPDC-based logistics firms to gain a competitive advantage through environmental adaptability. 
European Journal of Logistics, Purchasing and Supply Chain Management

Vol.8 No.2, pp.24-34, May 2020

Published by ECRTD UK

ISSN 2054-0930 (Print), ISSN 2054-0949 (Online)

\section{References}

Alexander, D. (2005). Towards the development of a standard in emergency planning, Disaster Prevention and Management, Vol. 14 No.2, pp.158-175.

Benyoucef, M., Forzley, S. (2007). Business continuity planning and supply chain management, Supply Chain Forum: International Journal, Vol. 8 No.2, pp.14-22.

Bigley, G.A., Roberts, K.H. (2001). The incident command system: high reliability organizing for complex and volatile task environments, Academy of Management Journal, Vol. 44 No.6, pp.1281-1299.

Boin, A., Lagadec, P. (2000). Preparing for the future: critical challenges in crisis management, Journal of Contingencies and Crisis Management, Vol. 8 No.4, pp.185-191.

Bowersox, D.J., Closs, D.J., Stank, T.P., Keller, S.B. (2000). How supply chain competency leads to business success, Supply Chain Management Review, Vol. 4 No.4, pp.70-8.

British Standards Institution (2006). BS 25999-1:2006 Business Continuity Management: Part 1 Code of Practice, SZC.

Carmeli, A., Schaubroeck, J. (2008). Organizational crisis-preparedness: the importance of learning from failures", Long Range Planning, Vol. 41 No.2, pp.177-196.

Carthey, J., de Leval, M.R., Reason, J.T. (2001). Institutional resilience in healthcare systems, Quality in Healthcare, Vol. 10 No.1, pp.29-32.

Claycomb, C., Germain, R., Dröge, C. (1999). Total system JIT outcomes interdependence: a theoretical analysis", Journal of Purchasing and Supply Management, Vol. 10 No.1, pp.39.

Cohen, S., Roussel, J. (2005). Strategic Supply Chain Management: The Five Inventory, organization and financial effects", International Journal of Physical Distribution and Logistics, Vol. 29 No.10, pp.612-30.

Cooper, M.C., Lambert, D.M. and Pagh, J.D. (1997). Supply chain management more than a new name for logistics, International Journal of Logistics Management, Vol. 8, No. 1, 113.

Cotton, E.A. (1993). Crisis! Lessons from the L.A. riots one year later, Public Utilities Fortnightly, Vol. 131 No.7, pp.20.

Crichton, M.T., Lauche, K., Flin, R. (2005). Incident command skills in the Disciplines for Top Performance, McGraw-Hill, New York, NY.

De Kluyver, C.A., Pearce, J.A. II (2006), Strategy: A View from the Top, 2nd ed., PearsonPrenticeHall, Upper Saddle River, NJ.

Elliott, D., Swartz, E., Herbane, B. (1999). Just waiting for the next big bang: business continuity planning in the U.K. finance sector, Journal of Applied Management Studies, Vol. 8 No.1, pp.43-60.

Elwood, A. (2009). Using the disaster crunch/release model in building organizational resilience, Journal of Business Continuity and Emergency Planning, Vol. 3 No.3, pp.241-247.

Gammelgaard, B., Larson, P.D. (2001). Logistics skills and competencies for supply chain management, Journal of Business Logistics, Vol. 22 No.2, pp.27-50.

Ghadge, A., Dani, S., Kalawsky, R. (2012). Supply chain risk management: present and future scope, International Journal of Logistics Management, Vol. 23 No.3,

Green, K.W. Jr, Inman, R.A. (2005). Using a just-in-time selling strategy to strengthen supply chain linkages, International Journal of Production Research, Vol. 43 No.16, pp.3437-53. 
European Journal of Logistics, Purchasing and Supply Chain Management

Vol.8 No.2, pp.24-34, May 2020

Published by ECRTD UK

ISSN 2054-0930 (Print), ISSN 2054-0949 (Online)

Green, K.W. Jr, McGaughey, R., Casey, K.M. (2006). Does logistics planning mediate the association between market orientation and organizational performance?, Supply Chain Management: An International Journal, Vol. 11 No.5, pp.407-14.

Green, K.W. Jr, Medlin, B., Whitten, D. (2004). Developing optimism to improve performance: an approach for the logistics sector, Industrial Management \& Data Systems, Vol. 104 No.2, pp.106-14.

Lambert, D.M., Cooper, M.C., Pagh, J.D. (1998). Supply chain management: implementation issues and research opportunities, The International Journal of Logistics Management, Vol. 9 No.2, pp.1-19.

Mallak, L. (1998). Putting organizational resilience to work, Industrial Management, Vol. 40 No.6, pp.8-13.

McManus, S. (2007). Organizational resilience in New Zealand, unpublished doctor of philosophy, University of Canterbury, Christchurch.

Morash, E.A., Clinton, S.R. (1997). The role of transportation capabilities in international supply chain management, Transportation Journal, Vol. 36 No.3, pp.5-17.

Ojha, D., Gokhale, R.A. (2009). Logistics planning-scale development and validation, International Journal of Logistics Management, Vol. 20 No.3, pp.342-359.

Pearson, C., Mitroff, I.I. (1993). From crisis-prone to crisis prepared: a framework for crisis management, The Academy of Management Executive, Vol. 7 No.1, pp.48-59.

Pearson, C.M., Clair, J.A. (1998). Reframing crisis management, The Academy of Management Review, Vol. 23 No.1, pp.59-76.

Rao, S., Goldsby, T.J. (2009). Supply chain risks: a review and typology, International Journal of Logistics Management, Vol. 20 No.1, pp.97-123.

Reason, J. (2000). Education and debate, human errors: models and management, British Medical Journal, Vol. 320 No.7237, pp.768-770.

Roth, E.M., Multer, J., Raslear, T. (2006). Shared situation awareness as a contributor to highreliability performance in railroad operations, Organization Studies, Vol. 27 No.7, pp.967-987.

Schramm-Klein, H., Morschett, D. (2006). The relationship between marketing performance, logistics performance and company performance for retail companies, International Review of

Retail, Distribution and Consumer Research, Vol. 16 No.2, pp.277-96.

Simon, H.A. (1957). Models of man: social and rational, Wiley, Oxford.

Tierney, K. (2003). Conceptualizing and measuring organizational and community Resilience: lessons from the emergency response following the September 11, Preliminary Study No. 329, 2001 Attack on the World Trade Center, University of Delaware, Newark, NJ.

Turner, B.A. (1976). The organizational and inter-organizational development of disasters, Administrative Science Quarterly, Vol. 21 No.3, pp.378-397.

Vecchio, R.P. (2000). Organizational behaviour core concepts, The Dryden Press, Fort Worth, TX, 4th ed.

Webb, G.R., Tierney, K.J., Dahlhamer, J.M. (2002). Predicting long-term business recovery from disaster: a comparison of the Loma Prieta earthquake and Hurricane Andrew, Environmental Hazards, Vol. 4 No.2, pp.45-58. 
European Journal of Logistics, Purchasing and Supply Chain Management

Vol.8 No.2, pp.24-34, May 2020

Published by ECRTD UK

ISSN 2054-0930 (Print), ISSN 2054-0949 (Online)

Weick, K.E. (1987). Organizational culture as a source of high reliability, California Management Review, Vol. 29 No.2, pp.112-127.

Wisner, J.D. (2003). A structural equation model of supply chain management strategies and firm performance, Journal of Business Logistics, Vol. 24 No.1, pp.1-26. 